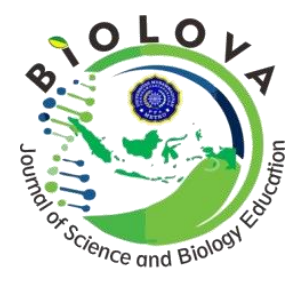

BIOLOVA

e ISSN 2716-473X

Universitas Muhammadiyah Metro

p ISSN 2716-4748

http://scholar.ummetro.ac.id/index.php/biolova/

DOI :

\begin{tabular}{l|lll|}
\hline History Article & Received: Maret 2020 & Approved: Maret 2020 & Published: Maret 2020 \\
\hline
\end{tabular}

\title{
ANALISIS PERKEBUNAN ORGANIK SEBAGAI SUMBER BELAJAR EKOSISTEM
}

\author{
Mia Cholvistaria ${ }^{1}$ \\ Hening Widowati ${ }^{2}$ \\ Universitas Muhammadiyah Metro \\ 1Email: miacholvis@yahoo.co.id, 2 Email: hwummetro@gmail.com
}

\begin{abstract}
Abstrak: Implementasi kurikulum 2013 saat ini menekankan kepada pembelajaran yang berbasis pada aplikasi kehidupan sehari-hari sesuai dengan pembelajaran saintifik. Penelitian ini bertujuan untuk mengobservasi dan menganalisis potensi sumber belajar pada kebun Organik 23 Karang Rejo Kota Metro dengan materi pokok Ekosistem kelas X SMA. Hasil kajian potensi sumber belajar yang diperoleh komponen biotik yaitu jenis tanaman sayuran, jenis tanaman bunga, insekta dan komponen abiotik yang membentuk jaring-jaring makanan dan siklus energi. Berdasarkan kriteria pembuatan bahan ajar yang terdiri atas kejelasan potensi, kejelasan sasaran, kesesuaian dengan tujuan belajar, kejelasan pedoman eksplorasi, kejelasan informasi yang dapat diungkap, kejelasan yang diperoleh diharapkan kajian sumber belajar untuk pengemasan bahan ajar dapat dijadikan acuan pengembangan bahan ajar berbasis lingkungan melalui penyesuaian terhadap Kurikulum 2013, karakteristik dan kebutuhan peserta didik.
\end{abstract}

Kata kunci: ekosistem, kebun organik, dan sumber belajar

Abstract: The current curriculum implementation in 2013 emphasizes learning based on the application of daily life in accordance with scientific learning. This study aims to observe and analyze the potential of learning resources in the Organic Garden 23 Karang Rejo Metro City with the subject matter of Ecosystem Class X SMA. The results of the study of the potential sources of learning obtained by biotic components, namely types of vegetable plants, types of flowering plants, insects and abiotic components that form food webs and energy cycles. Based on the criteria for making teaching materials consisting of clarity of potential, conformity with learning objectives, clarity of objectives, clarity of information that can be revealed, clarity of exploration guidelines, clarity of acquisition that is expected to study learning resources for packaging teaching materials can be used as a reference for the development of teaching materials based on local potential through adjustments to the 2013 curriculum, characteristics and needs of students.

Key Words : ecosystem, learning resources, organic gardens

\section{How to Cite}

Cholvistaria, Mia dan Hening Widowati. 2020. Analisis Perkebunan Organik sebagai Sumber Belajar Ekosistem. Biolova 1(2). 118-129. 
Penekanan Implementasi

kurikulum 2013 kepada pembelajaran saat ini yang berorientasi pada aplikasi kehidupan sehari-hari sesuai dengan pembelajaran saintifik. Pembelajaran saintifik mengutamakan pembelajaran yang menyentuh dalam tiga ranah yaitu ranah afektif, kognitif, dan psikomotor dimana tujuan pembelajaran menghasilkan peserta didik yang kreatif, produktif, inovatif dan efektif maka dalam hal ini dibutuhkan pengalaman belajar yang berbasis kontekstual khususnya pembelajaran biologi dapat memanfaatkan potensi lokal sebagai sumber belajar yang relevan. (Karwono 2012:140) sumber belajar dibagi menjadi dua yaitu sumber belajar yang didesain dan sumber belajar yang dimanfaatkan, dalam pemanfaatan sumber belajar, guru mempunyai tanggung jawab membantu peserta didik belajar yang terarah, lancar dan lebih mudah.

Kemampuan guru yang berhubungan dengan pemanfaatan sumber belajar adalah menggunakan sumber belajar dalam kegiatan pembelajaran sehari-hari, menyajikan sumber belajar, mengenalkan dan menerangkan peranan berbagai sumber belajar dalam pembelajaran, menyusun tugas-tugas penggunaan sumber belajar dalam bentuk tingkah laku, mencari sendiri bahan dari berbagai sumber, merencanakan kegiatan penggunaan sumber belajar secara efektif, dan menilai keefektifan penggunaan sumber belajar sebagai bagian dari kegiatan pembelajaran (Ditjend Dikti 1983:38-39 dalam Karwono 2012).

Sumber belajar dapat berfungsi sebagai saluran komunikasi dan mampu berinteraksi dengan siswa dalam suatu kegiatan pendidikan dan pembelajaran. Oleh sebab itu guru harus mengembangkan dan merancang sumber belajar secara sistematis berdasarkan kebutuhan kegiatan pembelajaran yang akan dilaksanakan dan juga berdasarkan pada karakteristik para siswa yang akan mengikuti kegiatan pembelajaran tersebut. Pemilihan sumber belajar yang berkualitas akan sangat bermakna dan bermanfaatan dalam pencapaian tujuan pembelajaran yaitu memberikan pemahaman yang mendalam terhadap peserta didik mengenai konsep-konsep sains yang relevan dan sesuai dengan pendekatan saintifik. Sumber belajar mencakup apa saja yang dapat digunakan untuk membantu seorang pendidik dalam kegiatan pembelajaran dan menampilkan kompetensinya (M Nur, 2012:15). Sumber belajar khususnya pembelajaran biologi dalam proses pembelajaran dapat diperoleh di sekolah atau di luar sekolah (Suryaningsih 2018:67).

Mulyasa (2011: 177-178) menjelaskan sumber belajar adalah salah satu bagian komponen penting yang menentukan suksesnya proses pembelajaran. Sumber belajar yang dipakai dalam satu proses pembelajaran hendaknya beraneka ragam sebagai upaya memperkaya informasi yang didapat oleh siswa. Sumber belajar dapat dirumuskan sebagai segala sesuatu yang dapat memberikan kemudahan kepada peserta didik dalam memperoleh sejumlah informasi, pengetahuan, pengalaman, dan keterampilan dalam proses pembelajaran. Sumber belajar yang ada, pada garis besarnya dapat dikelompokkan sebagai berikut: 1) Manusia (people), yaitu orang menyampaikan pesan secara langsung, seperti guru, konselor, dan administrator, yang dirancang secara khusus dan disengaja untuk kepentingan 
belajar (by design). Disamping itu ada juga orang yang tidak diniati untuk kepentingan pembelajaran tetapi memiliki keahlian yang bisa dimanfaatkan untuk kepentingan pembelajaran, misalnya penyuluhan kesehatan, polisi, pemimpin. Orang tersebut tidak diniati, tetapi sewaktuwaktu bisa dimanfaatkan untuk kepentingan pembelajaran; 2) Bahan (material), yaitu sesuatu yang mengandung pesan pembelajaran, baik yang dirancang secara khusus seperti film pendidikan, peta, grafik, buku, dan lain-lain yang disebut media pengajaran (instructional media), maupun bahan yang bersifat umum yang dapat dimanfaatkan untuk kepentingan belajar; 3. Lingkungan (setting), yaitu ruang dan tempat di mana sumbersumber dapat berinteraksi dengan para pesrta didik. Ruang dan tempat yang dirancang secara sengaja untuk kepentingan belajar, misalnya perpustakaan, laboratorium, kebun, dan lain-lain; 4. Alat dan peralatan (tool and equipment), yaitu sumber belajar untuk produksi dan atau memainkan sumbersumber lain yang digunakan sebagai alat penunjang dalam proses pembelajaran yang berlangsung, misalnya: tape recorder, kamera, slide; 5. Aktivitas (activities), yaitu sumber belajar yang biasanya merupakan kombinasi antara teknik dengan sumber lain untuk memudahkan belajar, misalnya pembelajaran berprogram merupakan kombinasi anatara teknik penyajian bahan dengan buku, contoh lainnya seperti simulasi dan karyawisata.

Pada salah satu kelurahan di kotamadya Metro Lampung yang bernama Kelurahan Karangrejo 23, Kota Metro yang dibina oleh Universitas Muhammadiyah Metro memiliki potensi lokal pertanian organik yang menjadi sumber belajar yang dapat dimanfaatkan baik dalam pembelajaran bagi peserta didik maupun sumber belajar masyarakat sekitar serta pengembangan menjadi desa wisata yang berupa peningkatan pengetahuan dan perekonomian masyarakat. Penanaman sayuran dengan organik menjadi daya tarik bagi masyarakat untuk menggali infomasi terkait dengan pentingnya memanfaatkan alam dengan cara yang sehat dan berkelanjutan serta hasil produksi yang memiliki nilai jual tinggi ditinjau dari konteks kesehatan dan nilai gizi sayuran.

Potensi lokal adalah kekayaan alam, budaya, dan SDM pada suatu daerah. Potensi alam di suatu daerah bergantung pada kondisi geografis, iklim, dan bentang alam daerah tersebut (Aditiawati, 2016: 59). Sehingga kebun organik Karang Rejo ini dinilai memenuhi syarat sebagai sumber belajar yang dapat dimanfaatkan sebagai sumber belajar yang berbasis lingkungan alam sekitar. Syarat-syarat sumber belajar (Djohar dalam Situmorang, 2016:55) yaitu: kejelasan potensi, kesesuaian dengan tujuan belajar, kejelasan sasaran, kejelasan informasi yang dapat diungkap, kejelasan pedoman penelitian, dan kejelasan perolehan yang diharapkan. Mengacu sistematika pembahasan yang berpedoman dengan syarat-syarat sumber belajar ini juga digunakan pada penelitian (Susilo 2014).

Berdasarkan pada potensi alam yang dijelaskan (Aditiawati, 2016: 59) dan syarat sumber belajar yang dijelaskan Djohar (Situmorang, 2016:55) didapat bahwa kebun organik Karang Rejo memiliki macam-macam jenis tanaman sayuran, tanaman bunga dan kolam ikan yang dimanfaatkan dalam pencucian sayuran sekaligus 
menernak ikan yang juga sisa-sisa sayuran bisa dimasukan kedalam kolam untuk dikonsumsi oleh ikan tersebut, tanaman serta kompenen biotik lain seperti sarang lebah trigona yang dibuat untuk membantu penyerbukan tanaman serta beberapa predator insekta yaitu iguana yang menjadi proses jaringan makanan dan interaksi antara faktor biotik dan abiotik. Tidak kalah penting pada kebun organik ini juga terhampar persawahan masyarakat sekitar yang dapat dijadikan sumber belajar yang relevan dan menyenangkan.

Lingkungan dan siklus jaringan makanan serta interkasi faktor biotik dan abiotik pada suatu lingkungan ini sangat berpotensi digunakan sebagai pelaksanaan pembelajaran biologi khususnya materi ekosistem. Kondisi ini didasarkan atas ketersediaanya objek pembelajaran biologi yang berpotensi menjadi bahan ajar biologi SMA. Secara alami lingkungan telah menyediakan berbagai sumber belajar yang bervariasi. Namun perlu pemanfaatan yang tepat dalam bentuk pengemasan bahan ajar dan disesuaikan dengan materi pembelajaran dan tujuan pembelajaran. With the teaching material that presents information on local culture, local ecosystems and the learning of field practice activities is expected to help students better understand the material, make the learning process more meaningful and be able to know the culture around them menjelaskan bahwa dengan bahan ajar yang menyajikan informasi tentang budaya lokal, ekosistem lokal dan pembelajaran kegiatan praktik lapangan diharapkan dapat membantu siswa lebih memahami materi, membuat proses belajar lebih bermakna dan dapat mengetahui budaya di sekitar mereka (N B Haka, 2020).

\section{METODE}

Penelitian ini adalah penelitian exspose facto melalui kegiatan observasi potensi lokal. Analisis potensi lokal yang dilakukan untuk mengetahui dan memanfaatkan lingkungan yang dapat dikaji untuk dijadikan sumber belajar yang dikemas dalam bahan ajar. Penelitian ini dilakukan dengan 3 tahapan yaitu identifikasi potensi lokal di dalam lingkungan Kebun Organik 23 Karangrejo Metro, identifikasi potensi lokal di luar lingkungan Kebun Organik 23 Karangrejo Metro, dan analisis potensi lokal pada materi biologi kelas X SMA.

Objek dalam penelitian ini adalah lahan pertanian organik dan komponen ekosistem yang ada di pertanian tersebut. Teknik pengumpulan data yang digunakan adalah observasi, wawancara, dokumentasi. Waktu penelitian dilakukan expose facto dengan materi ekosistem kelas X SMA. Data yang didapat selanjutnya dijelaskan secara deskriptif dan hasil analisis merupakan hasil gambaran fakta-fakta di lapangan. Survei dilakukan melalui pengamatan serta beberapa keterangan yang jelas terhadap suatu kajian potensi lokal. Penelitian ini merupakan studi pendahuluan, untuk dilanjutkan pada penelitian dalam skala luas, tentang bertani secara ramah lingkungan yang berkelanjutan. Diharapkan dari penelitian pendahuluan ini terkumpul data lengkap, sehingga pada akhirnya dapat disimpulkan melalui hasil interpretasi analisis.

\section{HASIL}

Identifikasi Potensi Lokal di dalam lingkungan Kebun Organik 23 Karangrejo Metro 
Kondisi lingkungan yang berada di Kebun Organik 23 Karang Rejo Metro memiliki banyak potensi lokal di antaranya adalah dilihat dari faktor biotik flora tersedianya beberapa jenis tanaman sayuran dan jenis tanaman bunga di antaranya pada tanaman sayuran bayam (Amaranthus sp), caisim (Brassica juncea L.), kangkung (Ipomoeae reptans), pakcoy (Brassica rapa L.), selada (Lactuca sativa L.), kemangi (Ocimum basilicum L.), terong ungu (Solanum melongena L.), cabai rawit (Capsicum frutescens $\mathrm{L}$ ), tomat (Solanum lycopersicum L.), kacang panjang (Vigna sinensis L.) dan lain-lain serta ditanami jenis tanaman bunga sebagai tanaman refugia menurut Septariani (2019: 2) tanaman refugia adalah pertanaman beberapa jenis tumbuhan yang dapat menyediakan tempat perlindungan, sumber pakan atau sumberdaya yang lain bagi musuh alami seperti predator dan parasitoid. Jenis tanaman refugia yang dimanfaatkan pada kebun organik Karang Rejo yaitu jenis tanaman bunga yang memiliki warna mencolok seperti Bunga tahi kotok (Tagetes erecta L) dan Bunga kertas (Cosmos radiance) yang berfungsi untuk menarik serangga yang merupakan hama untuk tidak merusak tanaman sayuran yang ada di kebun organik Karang Rejo. Sedangkan fauna yang ada di dalam lingkungan kebun terdapat semut, iguana/Bronchocela jubata L.) (bunglon surai), lebah trigona, kupu-kupu, jangkrik, cacing dan burung. Dari faktor abiotik ada cahaya matahari, air, batu, tanah, suhu, dan kelembaban.

Untuk lebih jelas potensi lokal kebun organik yang dapat dimanfaatkan sebagai sumber belajar materi ekosistem dapat dilihat dari hasil dokumentasi gambar/foto dan tabel berikut.

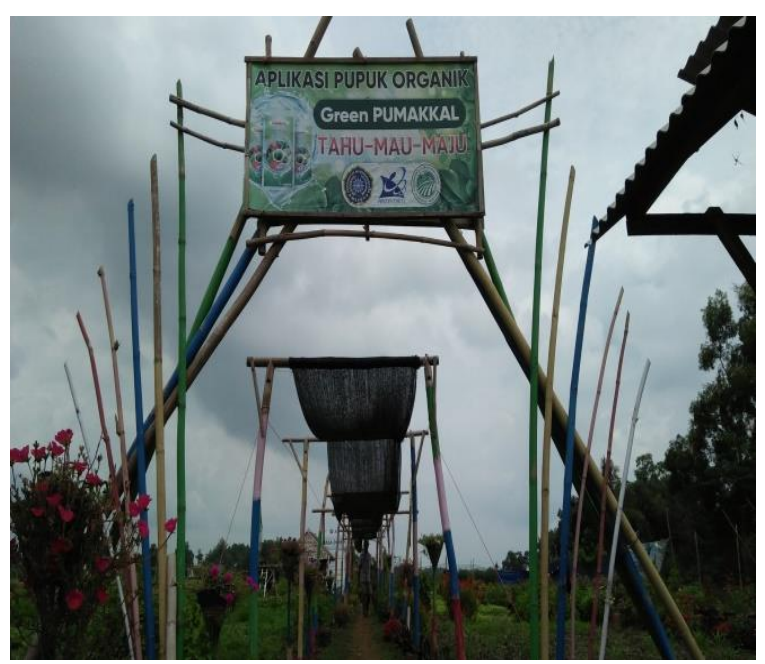

Gambar 1. Potensi Desa Wisata Kebun Organik 23 Karang Rejo Kota Metro

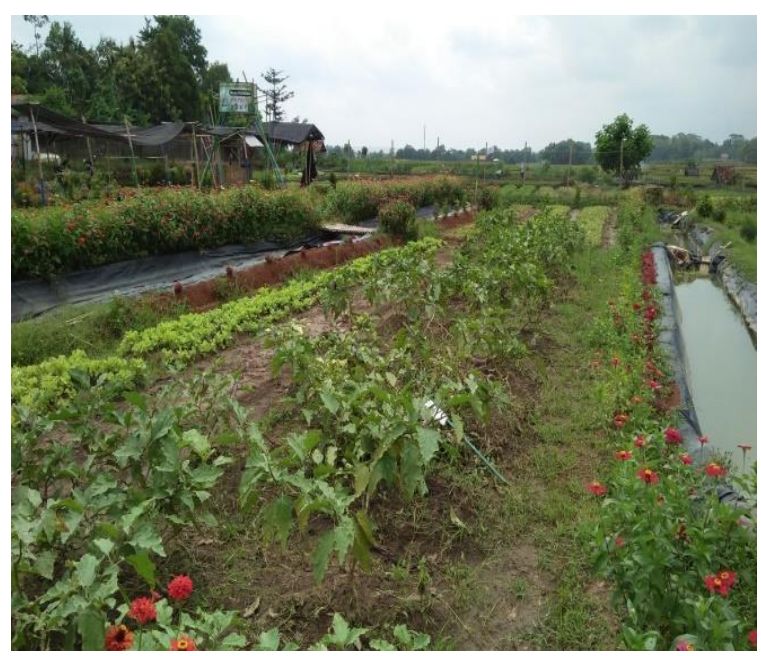

Gambar 2. Jenis Sayuran dan Kolam Ikan 


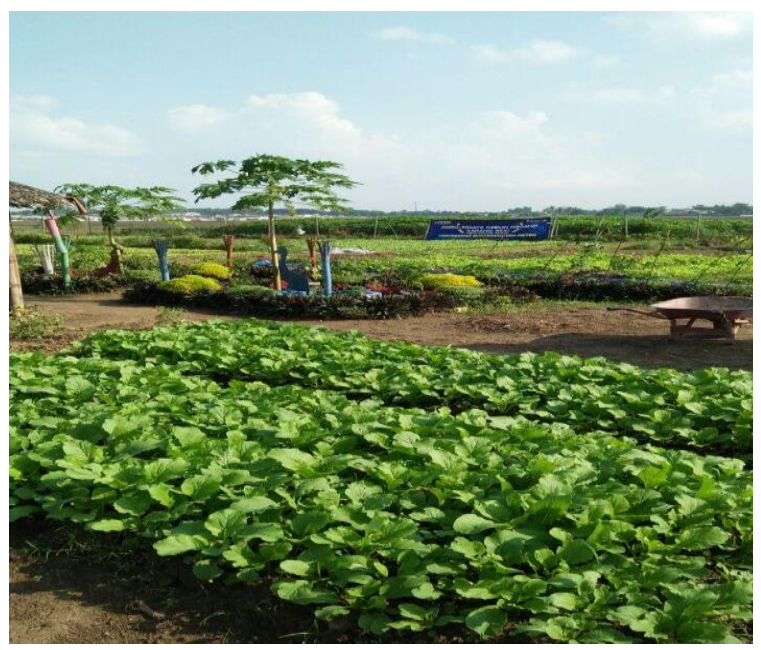

Gambar 3. Tanaman Sayuran dalam Proses Pertumbuhan.

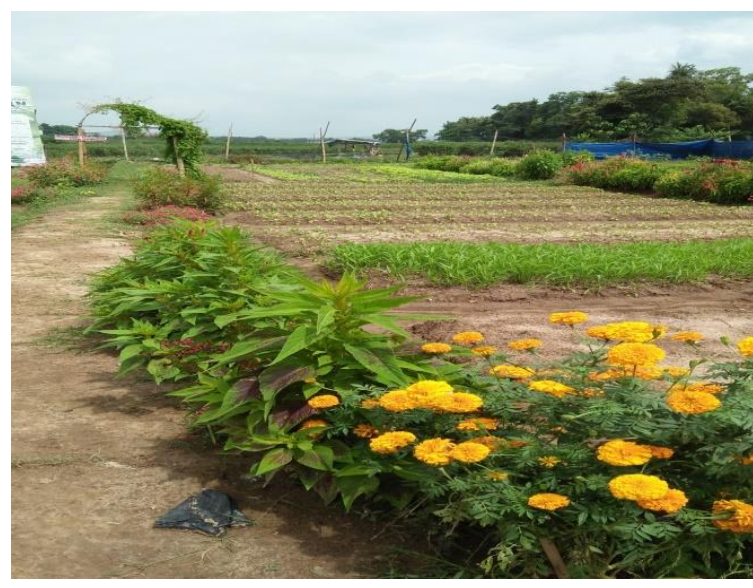

Gambar 4. Tanaman Bunga Tahi Kotok

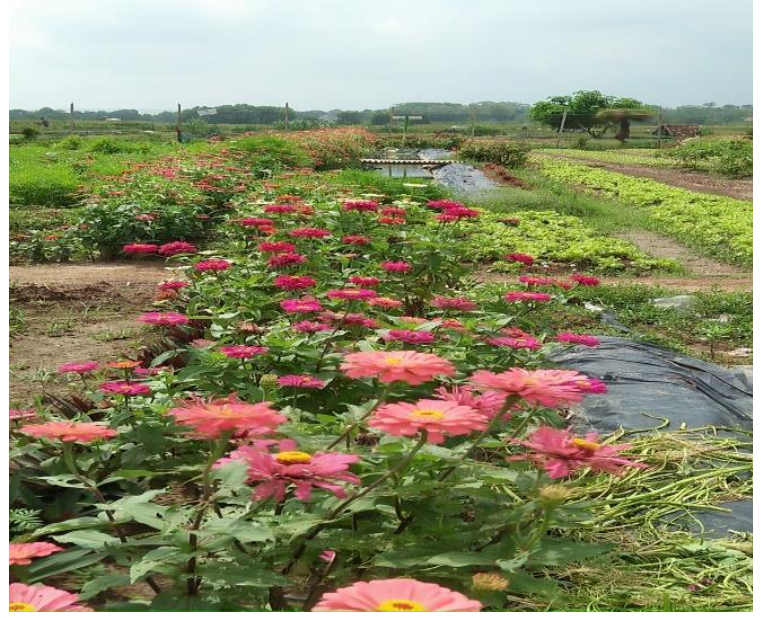

Gambar 5. Tanaman Bunga Kertas

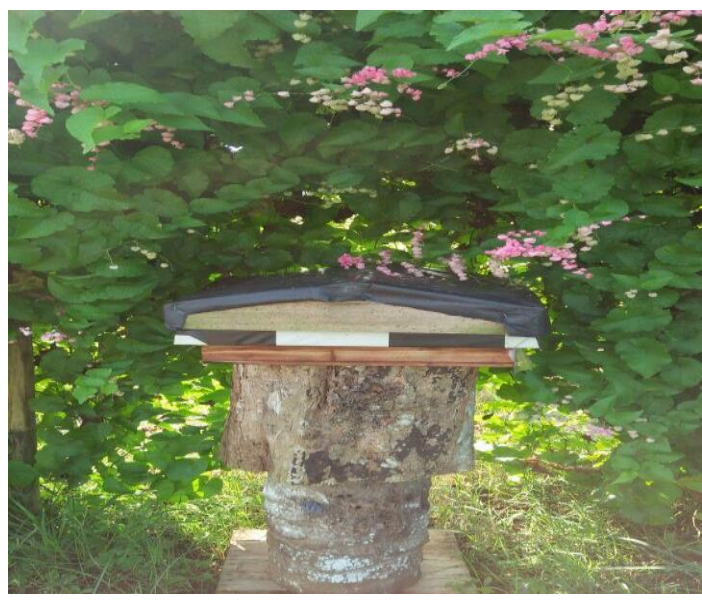

Gambar 6. Sarang Lebah Trigona

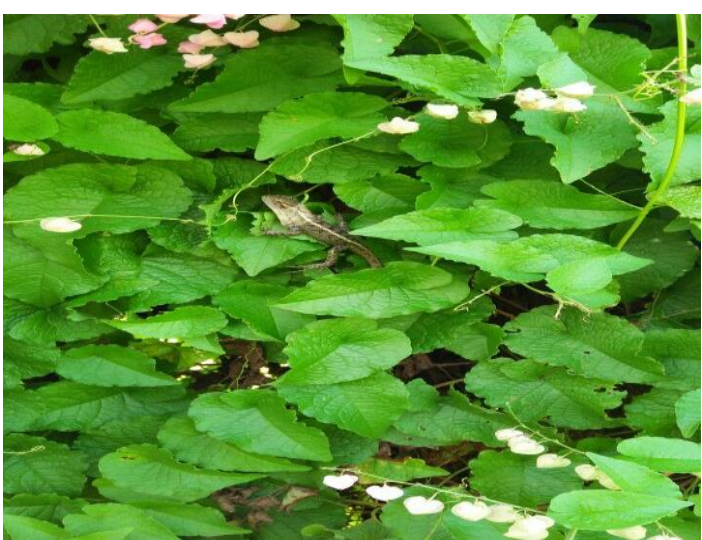

Gambar 7. Iguana/bunglon surai (Bronchocela jubata L.) yang Tinggal di Kebun Organik

Komponen Abiotik dan Biotik yang Teridentifikasi pada Kebun Organik Karang Rejo Metro sebagai berikut.

Tabel 1. Hasil Identifikasi Komponen Abiotik

\begin{tabular}{|c|c|c|}
\hline No & $\begin{array}{l}\text { Komponen } \\
\text { Abiotik }\end{array}$ & Keterangan \\
\hline 1. & Sinar Matahari & Semua \\
\hline 2. & Air & organic \\
\hline 3. & Batu & terdapat komponen abiotic \\
\hline 4. & Tanah & dengan suhu berkisar $28^{\circ}$ \\
\hline 5. & Suhu & C dengan \\
\hline 6. & Kelembaban & $\begin{array}{l}\text { mencapai } 76 \% \text { dan curah } \\
\text { hujan } 7 \% \text {. }\end{array}$ \\
\hline
\end{tabular}


Tabel 2. Hasil Identifikasi Komponen Biotik

\begin{tabular}{lll}
\hline \multicolumn{2}{c}{ Spesies temuan } & Lokasi \\
\cline { 1 - 2 } flora & \multicolumn{1}{c}{ Fauna } & \\
\cline { 1 - 2 } Sayuran bayam, & Semut, & Sekitar \\
caisim, kangkung, & iguana, & kebun \\
pakcoy, selada, & lebah & organik \\
terong ungu, & kupu-kupu, & 23 \\
kemangi, kacang & capung, & rejo \\
panjang dan & Jangkrik, & \\
tanaman bunga tahi & cacing, & \\
kotok & burung. & \\
\hline
\end{tabular}

\section{Identifikasi Potensi Lokal di Luar Lingkungan Kebun Organik 23 Karangrejo Metro}

Berdasarkan hasil identifikasi komponen-komponen ekosistem yang ada pada kebun organik 23 Karang Rejo Metro adalah potensi lokal yang berada diluar kebun organik 23 Karang Rejo Metro adalah hamparan luas tanaman sayuran non organik dan sebagian hamparan sawah. Lingkungan di luar kebun juga ikut mendukung bahkan berpotensi sebagai sumber belajar materi ekosistem yaitu ekosistem sawah dimana unsur biotik yang berbeda dengan unsur biotik yang ada di perkebunan organik ditinjau dari flora dan fauna yang terdapat dalam ekosistem tersebut. Umumnya masyarakat di sekitar daerah ini adalah petani. Lahan pertanian dikelola oleh swadaya masyarakat atau secara berkelompok dan mandiri dengan proses bertanam yang konvensional. Kegiatan bercocok tanam secara tradisional yang dilakukan oleh para petani secara turuntemurun dari orang tua terdahulu. Jenis lahan adalah lahan basah dan sawah tadah hujan. Hasil bercocok tanam yaitu beberapa jenis sayuran dan tanaman padi.
Potensi lokal di luar perkebunan organik Karang Rejo yang dapat dimanfaatkan sebagai sumber belajar dapat dilihat dari hasil dokumentasi berikut:

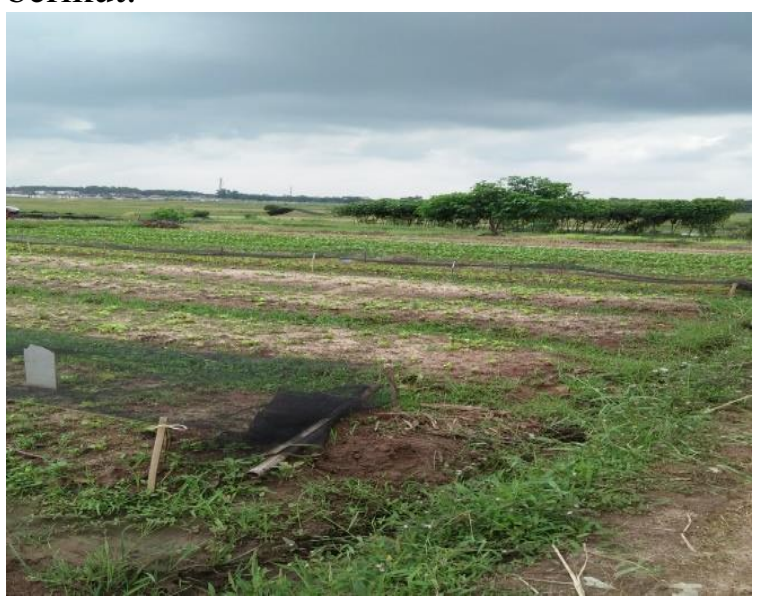

Gambar 7. Tanaman di Luar Sekitar Kebun Organik 23 Karang Rejo Metro

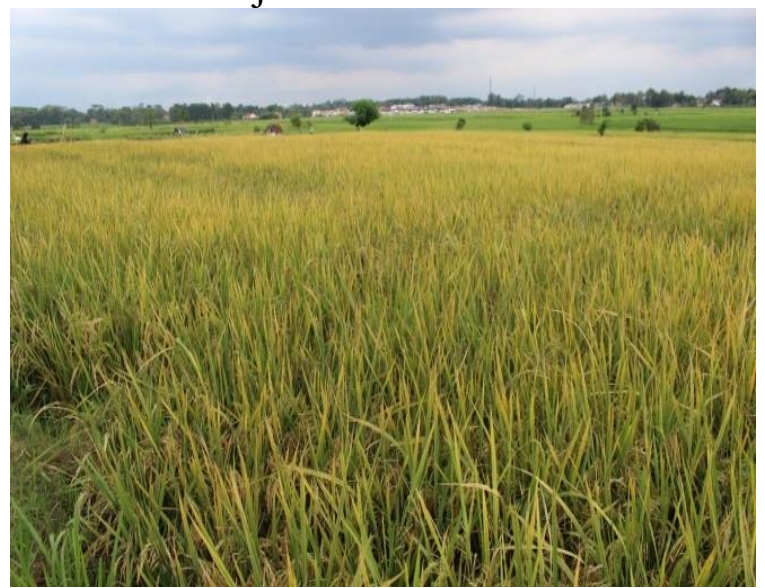

Gambar 8. Persawahan di luar sekitar Kebun Organik 23 Karang Rejo Metro

\section{PEMBAHASAN}

Berdasarkan potensi lokal komponen biotik yang terdapat di sekitar area pertanian kebun organik 23 Karang Rejo Metro dapat diketahui dominansi flora yaitu: sayuran bayam, caisim, kangkung, cabai rawit, tomat, pakcoy, selada, terong ungu, kemangi, kacang panjang dan tanaman bungai tahi 
kotok dan bunga kertas. Dominansi fauna yang ditemukan antara lain: semut, iguana, lebah trigona, kupukupu, capung, jangkrik, cacing dan burung. Selanjutnya temuan komponen abiotik dan biotik yang berbasis potensi lokal tersebut ditelaah untuk mengetahui apakah berpotensi sebagai sumber belajar biologi SMA untuk materi ekosistem. Hasil pengkajian diperoleh hasil sebagai berikut:

Tabel 3. Potensi untuk Sumber Belajar Biologi SMA

\begin{tabular}{|c|c|c|c|}
\hline \multirow[t]{2}{*}{ No } & \multirow{2}{*}{$\begin{array}{l}\text { Potensi } \\
\text { Kebun } \\
\text { Pertanian } \\
\text { Organik }\end{array}$} & \multicolumn{2}{|c|}{$\begin{array}{l}\text { Kesesuaian } \\
\text { potensi belajar } \\
\text { dengan kurikulum } \\
2013\end{array}$} \\
\hline & & sesuai & $\begin{array}{l}\text { Tidak } \\
\text { sesuai }\end{array}$ \\
\hline 1. & $\begin{array}{l}\text { Komponen } \\
\text { Biotik }\end{array}$ & $\sqrt{ }$ & - \\
\hline 2. & $\begin{array}{l}\text { Komponen } \\
\text { Abiotik }\end{array}$ & $\sqrt{ }$ & - \\
\hline
\end{tabular}

Dengan mengacu pada kesesuaian terhadap syarat-syarat sumber belajar menurut Djohar (Situmorang, 2016:55), yaitu: kejelasan potensi, kesesuaian dengan tujuan pembelajaran, kejelasan sasaran, kejelasan informasi yang diungkap, kejelasan pedoman penelitian, kejelasan perolehan yang diharapkan, maka dapat dibahas sebagai berikut:

a. Kejelasan potensi Kondisi lingkungan yang ada di lingkungan sekitar perkembunan pertanian organic 23 karangrejo Kota Metro dapat diangkat dan dijadikan sebagai sumber belajar yang menarik bagi siswa, karena proses belajar mengajar tidak hanya dapat dilakukan di dalam kelas, akan tetapi dapat pula dilakukan diluar ruangan kelas. Pembelajaran kontekstual menjadi kebutuhan peserta didik saat ini. Perlunya kajian terhadap potensi lokal bertujuan untuk mengajak peserta didik untuk bersentuhan langsung dengan objek materi biologi dalam bentuk aktivitas dan eksperimen.

Ketersedian objek pembelajaran dalam bentuk potensi lokal diharapkan mengajak peserta didik untuk mengungkap banyak fenomena dan fakta-fakta sehingga dapat lebih mengenal lingkungannya melalui pemahaman konsep bahan ajar. Potensi yang ada di daerah ini yang ditemukan dapat dijadikan sebagai sumber belajar yang sesuai dengan kebutuhan belajar siswa yakni dapat mengetahui secara langsung komponen abiotik dan biotik yang ada dalam suatu ekosistem buatan yaitu ekosistem sawah, adanya interaksi antara komponen biotik dan abiotik, serta terjadinya proses jaringan makanan yang ada di ekosistem tersebut. Berdasarkan analisis materi menurut kurikulum 2013 Kompetensi Inti yaitu mengolah, menalar, dan menyaji dalam ranah konkret dan ranah abstrak terkait dengan pengembangan dari yang dipelajari di sekolah secara mandiri, dan mampu menggunakan metode sesuai kaidah keilmuan dan berdasarkan Kompetensi Dasar 4.9 Kurikulum 2013 yaitu mengelompokkan berbagai jenis mahluk hidup pada tingkat gen, jenis dan ekosistem dari berbagai objek dan atau menggunakan gambar, dapat diidentifikasi bahwa komponen ekosistem yaitu adanya interaksi antar komponen ekosistem dan jejaring makanan yang berlangsung dalam ekosistem. Berdasarkan permasalahan di atas dapat dijadikan sumber belajar yang sesuai dengan materi pokok komponen ekosistem dan interaksi dalam ekosistem. 
b. Kejelasan Sasaran

Kejelasan sasaran untuk materi ekosistem memiliki subjek dan objek yang kongkrit atau nyata dan memberikan kemudahan bagi guru dalam menerapkan pendekatan saintifik dalam pembelajarannya berbasis lingkungan.

c. Kesesuaian dengan tujuan pembelajaran Potensi lokal yang ditemukan di area perkebunan pertanian organik jika dikaitkan dengan tujuan pembelajaran pada materi ekosistem yang mengacu pada kurikulum 2013. Hasil kajian yang diperoleh melalui penelitian memiliki kesetaraan dengan kompetensi dasar (KD) dan kompetensi inti (KI) dalam kurikulum 2013. Adapun kesesuaian materi yang dimaksud adalah pada materi Ekosistem kelas X SMA.

d. Kejelasan informasi yang akan diungkap Informasi yang akan diungkap berdasarkan hasil penelitian yang berbasis pada potensi lokal sehingga dekat dengan sekolah-sekolah setempat. Informasi yang dapat diungkap dari hasil penelitian eksplorasi ini berupa proses dan produk penelitian. Informasi berupa proses dalam penelitian ini yaitu menggunakan pendekatan penelitian eksplorasi dengan sistem jelajah, sehingga memudahkan siswa untuk melakukannya. Informasi produk penelitian ini berupa laporan penelitian yang dilengkapi dengan metodologi yang jelas dan dokumen-dokumen foto hasil identifikasi komponen Ekosistem yang terdapat di Kelurahan Karang Rejo 23 Kota Metro.

e. Kejelasan Pedoman Penelitian Pedoman penelitian agar diperoleh hasil yang maksimal diperlukan prosedur kerja penelitian yang meliputi penentuan tempat penelitian, alat dan bahan, cara kerja, pengolahan data serta penarikan kesimpulan. Keterbatasan waktu yang ditentukan di sekolah dan kemampuan siswa menjadi pertimbangan, karena dengan adanya pemilihan kegiatan yang akan dilaksanakan siswa, agar kegiatan berjalan sesuai dengan yang diharapkan maka: harus menyesuaikan waktu agar proses pembelajaran dapat berlangsung dan mengalokasikan waktu untuk kegiatan ekstra kurikuler dan intra kurikuler.

f. Kejelasan perolehan yang diharapkan yaitu perolehan yang disesuaikan dengan standar isi kurikulum 2013 SMA, maka perolehan yang dimaksud berupa: 1) Perolehan afektif, siswa akan memiliki sikap-sikap ilmiah yang positif dalam ikut serta menjaga, memelihara, dan memanfaatkan alam dan lingkungan untuk tujuan-tujuan kebaikan. 2) Perolehan kognitif siswa yaitu mampu menggunakan cara berpikir kritis untuk mendapatkan pengetahuan dan pemecahan permasalahan melalui kegiatan pengamatan lingkungan sebagai sumber belajar sehingga mengalami peningkatan secara akademik hal ini sesuai dengan hasil penelitian (Senel 2020: 1) yang mengungkapkan bahwa context-based learning has a positive effect on motivation as well as on academic success yang diartikan bahwa pembelajaran berbasis konteks memiliki efek positif pada motivasi serta keberhasilan akademik. 3) Perolehan psikomotirik, psikomotor adalah domain yang meliputi perilaku gerakan dan koordinasi jasmani, keterampilan motorik dan kemampuan fisik seseorang. Keterampilan yang akan berkembang jika sering melakukan praktik dalam kegiatan pembelajaran 
yang dapat diukur berdasarkan jarak, kecepatan, kecepatan, teknik dan cara pelaksanaan. Dalam proses pembelajaran pemanfaatan sumber belajar ini dapat meningkatkan keterampilan siswa seperti keterampilan dalam menggali informasi, menganalisis, mengidentifikasi, mengimplementasikan sikap ilmiah peserta didik baik dalam melakukan pembelajaran maupun dalam berkomunikasi satu dengan lain, dan lain sebagainya yang lebih pada melatih kemandirian siswa untuk bisa mengimplementasikan ilmu yang diperoleh dari sekolah ke masyarakat dan lingkunganya.

\section{KESIMPULAN}

Mengacu pada hasil penelitian dalam penelitian ini maka dapat disimpulkan, bahwa komponen ekosistem kebun pertanian organik 23 Karang Rejo Kota Metro tersusun atas komponen abiotik yang terdiri sinar matahari, batu, tanah, air, suhu dan kelembaban dan komponen biotik yang terdiri dari flora dan fauna, seperti: tanaman sayuran, tanaman bunga dan beberapa fauna seperti semut, cacing, capung, kupukupu, lebah trigona, jangkrik dan burung serta bunglon surai. Hasil identifikasi dan analisis temuan tersebut untuk menjadi sumber belajar telah memenuhi persyaratan sumber belajar yang mencakup kejelasan potensi, kejelasan sasaran, kesesuaian dengan tujuan pembelajaran, kejelasan informasi yang diungkap, kejelasan pedoman penelitian, kejelasan perolehan yang diharapkan, sehingga mampu menghantarkan siswa pada: 1) Perolehan afektif, siswa akan memiliki sikap-sikap ilmiah yang positif dalam ikut serta menjaga, memelihara, dan memanfaatkan alam dan lingkungan untuk tujuan-tujuan kebaikan. 2) Perolehan kognitif siswa yaitu mampu menggunakan cara berpikir kritis untuk mendapatkan pengetahuan melalui kegiatan inquiry discovery. 3) Perolehan psikomotirik, psikomotor adalah domain yang meliputi perilaku gerakan dan koordinasi jasmani, keterampilan motorik dan kemampuan fisik seseorang. Keterampilan yang akan berkembang jika sering melakukan praktik dalam kegiatan pembelajaran yang dapat diukur berdasarkan jarak, kecepatan, kecepatan, teknik dan cara pelaksanaan. Dalam proses pembelajaran pemanfaatan sumber belajar ini dapat meningkatkan keterampilan siswa seperti keterampilan dalam menggali informasi, menganalisis sumber belajar, mengidentifikasi materi dan permasalahan, mengimplementasikan sikap ilmiah peserta didik baik dalam melakukan pembelajaran maupun dalam berkomunikasi satu dengan lain, dan lain sebagainya untuk lebih pada melatih kemandirian siswa dalam mengimplementasikan ilmu yang diperoleh disekolah saat berada ditengah-tengah masyarakat dan lingkungannya serta tertanam rasa mencintai lingkungannya sebagai komponen kehidupan yang harus dipeliharan dan dijaga keberlanjutannya.

\section{SARAN}

Untuk penelitian lanjut, sebagai pelengkap penelitian setipe, disarankan untuk melakukan identifikasi yang lebih rinci baik pengamatan lapangan maupun wawancara masyarakat sekitar untuk mendapatkan data yang lebih valid dan lengkap serta dokumentasi semua komponen baik faktor utama maupun faktor pendukung penelitian. 


\section{DAFTAR RUJUKAN}

Aditiawati, Pingkan, Dea Indriani Astuti, Gede Suantika, Togar M. Simatupang. 2016. Pengembangan Potensi Lokal di Desa Panawangan sebagai Model Desa Vokasi dalam Pemberdayaan Masyarakat dan Peningkatan Ketahanan Pangan Nasional. Jurnal Sosioteknologi. 15(1): 5967.

A Munandar, K Kusnasi., Munandar. 2019. Project-based Learning to Enhance Student's Awareness Towards The Environment. Journal of Physics: Conference Series International Conference on Mathematics and Science Education 2019 (ICMScE 2019). Vol 1521. Publish 22 May 2020.

Karwono., Heni Mularsih. 2012. Belajar dan Pembelajaran serta Pemanfaatan Sumber Belajar. Jakarta: PT Raja Grafindo Persada.

Megasari, Rika. 2014. Peningkatan Pengelolaan Sarana dan Prasarana Pendidikan untuk Meningkatan Kualitas Pembelajaran di SMPN 5 Bukit Tinggi. Jurnal Universitas Negeri Padang. Volume 2 Nomor 1, Juni 2014. Halaman 636 - 831.

M Nur, Faizah. 2012. Pemanfaatan Sumber Belajar dalam Pembelajaran Sains Kelas V SD pada Pokok Bahasan Makhluk Hidup dan Proses Kehidupan. Jurnal JESBIO. Vol 1 No1. Hal 14-20.

Mulyasa. 2011. Manajemen Berbasis Sekolah, Konsep, strategi dan
Implementasi. Bandung : PT Remaja Rosdakarya.

N B Haka, B S Anggoro, A Hamid, A Novitasari1, A Handoko, L Puspita. 2013. The Development of Biology Module Based on Local Wisdom of West Lampung: Study of Ecosystem Material. Journal of Physics Conference Series. Volume 1467.

R Masdiana, K Kusnadi A Munandar. 2020. Project-Based Learning to Enhance Student's Awareness Towards The Environment. Journal of Physics: International Conference on Mathematics and Science Education 2019 (ICMScE 2019). Vol 1521 (2020) 042005.

Senel, Hakan. 2020. Content Analysis of Biology Education Research That Used Context-Based Approaches: The Case of Turkey. Journal Makrothnik Institute. Volume 6 No 9 Page 203-208.

Septariani, Dwiwiyati Nurul., Aktavia Herawati., Mujiyo. 2019. Pemanfaatan berbagai Tanaman Refugia sebagai Pengendali Hama Alami pada Tanaman Cabai (Capsicum annum 1.). Journal of Community Empowering a Services. Vol 3(1), 2019.

Suryaningsih, Yeni. 2018. Ekowisata sebagai Sumber Belajar Biologi dan Strategi untuk Meningkatkan Kepedulian Siswa terhadap Lingkungan. Jurnal Bio Education. Volume 3, Nomor 2, Oktober 2018, hlm. 59- 72

Susilo, Muhammad Joko. 2014. Potensi Sumber Belajar Biologi 
SMA Kelas X Versi Kurikulum 2013 untuk Materi Ekosistem Sawah di Sekitar Gunung Puyuh Pundong Kabupaten Bantul. Proceeding Biology Education Conference. Hal 1032-1038. Semarang: Universitas Sebelas Maret. 